\title{
Role Colour Plays in Influencing Consumer Behaviour
}

\author{
Rupa Rathee; Pallavi Rajain \\ Department of Management Studies, Deenbandhu Chhotu Ram University of Science and Technology, \\ $50^{\text {th }}$ K.M. Stone, N.H. 1, Murthal, Haryana 131039, India
}

\begin{tabular}{l} 
A R T I C L E I N F O \\
\hline Keywords: \\
Colour, \\
Meaning, \\
Associations, \\
Sensory Marketing, \\
Consumer Behaviour \\
\\
Kata Kunci: \\
Warna, \\
Makna, \\
Asosiasi-asosiasi, \\
Sensory Marketing, \\
Perilaku Konsumen.
\end{tabular}

Corresponding author:

pallavirajain@gmail.com

\section{A B S T R A C T}

The ability of colours to attract attention has been used for a long time by marketers to gain customer's attention. A product with attractive packaging is bound to lure customers and stand apart from other products kept on the shelf. It has been found in several studies that if there is a mismatch in representation of colour associations the colour becomes an eyesore. Therefore, the present study was conducted to understand the role colour plays in influencing consumer behaviour. For this an online survey form was circulated among respondents to study their colour preferences. It was found that yellow colour was preferred the least and blue the most. There were significant differences in choices made by the two genders. The results indicated that colour influenced customer's decision and brand recall while making purchases. It was also found that there was significant difference among respondents regarding purchase of warm and cool colours as well as warm and neutral colours.

\section{SARI PATI}

Kemampuan warna untuk menarik perhatian telah digunakan sejak lama oleh pemasar untuk mendapatkan perhatian pelanggan. Sebuah produk dengan kemasan menarik memikat pelanggan dan berdiri terpisah dari produk lain yang disimpan di rak. Telah ditemukan dalam beberapa penelitian, jika ada ketidakcocokan dalam representasi asosiasi warna, warna justru merusak pemandangan. Oleh karena itu, penelitian ini dilakukan untuk memahami peran warna dalam mempengaruhi perilaku konsumen. Untuk ini formulir survei online diedarkan di antara responden untuk mempelajari preferensi warna mereka. Ditemukan bahwa warna kuning adalah yang paling kurang disukai dan biru paling disukai. Ada perbedaan signifikan dalam pilihan yang dibuat oleh kedua jenis kelamin. Hasil penelitian menunjukkan bahwa warna mempengaruhi keputusan pelanggan dan ketertarikan merek saat melakukan pembelian. Ditemukan juga bahwa ada perbedaan yang signifikan antara responden, terkait dengan pembelian warna hangat dan dingin, serta warna hangat dan netral.

(c) 2019 IRJBS, All rights reserved. 


\section{INTRODUCTION}

Colour is an integral part of the sensory marketing tactics. It influences consumers' behaviour and perceptions, induces moods and emotions; and helps companies in positioning or differentiating from the competitors. For several years, advertisers have recognized the visual attraction of different colours. Labrecque and Milne (2012) stated that to create an identity in the marketplace brands employed colour and this sets themselves apart from competition. An example of this is Pepsi claiming blue as the colour associated with their brand whereas red is the colour associated with Coca-Cola. For customers, differentiation has been created between the two brands based on these colour associations. Thus, the colour associated with a brand serves as a source of recognition and also reinforces the identity of the brand (Abril et al., 2009). The model of psychological functioning and colour developed by Elliot et al. in 2007, explained six principles: "colours represent certain significance; colour significance is derived from two foundations: biology and learned associations; colour triggers the assessment of stimuli; in turn, this assessment motivates behaviour; the process from recognizing significance to the motivational behaviour is all non-conscious; and colour evokes varied feelings in different circumstances" (Elliot and Maier, 2007, p.251).

According to research "colours with a longer wavelength- such as red, orange and yellowas warm colours, while those with a shorter wavelength- such as green, blue and violet- are described as cool" (Crowley, 1993, p.60). Usually, warm colours like yellow and red have produced opposite psychological and physiological effects in comparison to cool colours like green and blue, that are on the opposite ends of spectrum of colour (Bellizzi and Hite, 1992). Even though white is normally considered as neutral, it is occasionally credited to the category of cool colours (Chebat and Morrin, 2007). Psychologically, it is thought that emotions are aroused by warm colours for example red, which are also considered to be distracting and exciting while cool colours such as blue are linked to feelings of calmness, peacefulness, relaxation and pleasantness. Similarly, according to physiology, red in comparison to blue colour is considered to be more stimulating in connection with blood pressure, skin-conductance and respiratory rate. (Roschk et al., 2016). Colours often play such an important role because they are associated with buyer's beliefs or cultures. It may be noted that, in place of the colours themselves having an influence on individuals, the symbolic meanings instilled by colours in various cultures, are responsible for observed effects (Chebat and Morrin, 2007). As a variable in the atmosphere, colour describes the visible view of the environment where the goods or services are purchased or consumed (Bellizzi et al., 1983). Similar to a package design, in the retail store design as well, colour is used to draw or to attract the customer along with getting attention (Bellizzi and Hite, 1992). Over a long period, several studies have been performed concerning the psychological and physiological impact of colour. Very few studies have been available with respect to implications for marketing.

Table 1. Classification of colours into warm, neutral, cool colours

\begin{tabular}{lll}
\hline Warm colours & Neutral colours & Cool colours \\
\hline Red, orange, & Black, white, & Blue, green, \\
yellow & gray & purple \\
\hline
\end{tabular}

Source: Literature review

Marketers are usually not unaware of the impact of colour. Therefore, this study was carried out to understand the role that colour plays in influencing consumer behaviour. Such a study would help marketers understand the significance of colours and in turn allow them to make use of different colours according to the context and situation at hand.

\section{REVIEW OF LITERATURE}

\section{Colour and consumer behaviour}

In an experimental research Bellizzi and Hite (1992) probed the role of colour in creating the 
mood which affects the emotional states resulting in vital buyer responses. Two experiments were conducted whereby in experiment 1 , a sample of 70 women was subjected to either of two displays (red/blue) and in experiment 2, a sample of 107 students was subjected to slides of interiors of retail furniture with either red or blue interiors. The outcomes of the two experiments clearly showed more positive consumer reactions to blue. Similarly, Crowley (1993) proposed that there were no less than two dimensions within human response to colour. Subjects in this study consisted females with a sample size of hundred and between the ages of eighteen and sixty-four, selected with a non-probability convenience sampling method. The subjects were assigned at random to one of the four colour conditions which included red, yellow, green and blue. A furniture store setting was used with the colour of the stimulus used as the workable colour of the background, with all aspects of the stimulus except colour kept constant across subjects. A twenty items scale with semantic differential was employed in order to observe the existence of separate components within consumer responses to the stimuli, which was subjected to principal components analysis using the rotation method known as varimax. "Two dimensional" hypothesis was corroborated by the outcomes of this study. The environment of a retail store in the more extreme wavelength colours i.e. blue and red were perceived as more lively environments. A different dimension for evaluation was also found in ratings of consumers for the store environments, wherein the evaluations became steadily more positive as wavelength changed from warmer to cooler hues. Grossman and Wisenblit (1999) applied a framework based on associative learning to colour literature in order to help in understanding the colour choices of buyers. The classical conditioning principles were used to form an understanding of associative learning which were further used to give implications. Principles of classical conditioning make it easier for marketers to make use of associations when stimuli are similar or resemble each other in some way.
Chebat and Morrin (2007) discovered the effects of cool versus warm coloured mall decorations on shopper perceptions by subculture. The authors found that the perception of Franco-Canadians was higher regarding product quality when warm colour decoration was found within the mall. As opposed to Canadians, English-Canadians had high perceptions of quality of product when cool colour decoration was found in the mall. The analysis indicated that the perceptual developments were mediated mainly by cognitive rather than affective mechanisms.

Singh (2006) conducted a literature review related to psychology of colour in the milieu of marketing, highlighted controversies and anomalies around the psychology of colour and examined the influence of colours in selling products. First, he gave a background of colour and how it is perceived. Colour is "light carried on wavelengths absorbed by the eyes that the brain converts into colours that we see". Secondly the author studied the effect of colour on various aspects like health, culture, emotions and gender. It was found that different colours had varying effects on the health of the people ranging from red energizing the liver to blue creating calmness and relaxation. Next the author focused on the application of colour in marketing. Because of its influence on human metabolism it was found that the red colour stimulated appetite in restaurants making red a prevalent choice of colour among fast-food restaurants. On further studying the effects of colours it was found that they influenced the realization of time passage. In future researches, before the launch of a product, an investigation relating to the choice of colours should be carried out and summarized as there can be negative influence of inaccurate choice of colour on the product image as well as the company. Kaya (2004) conducted a study among college students in order to study the association between colour and emotion. The sample included 98 students of a college who were requested to specify their emotional responses to five primary hues which included green, purple, red, blue and yellow; five intermediate hues that is yel- 
low-red, green-yellow, blue-green, purple-blue, and red-purple; and three achromatic colours including black, gray and white; and the explanation for their choices. The research suggested that the maximum number of positive emotional replies were covered by primary hues, these were followed by the intermediate hues and lastly the achromatic colours. Positive emotions such as comfort and relaxation were evoked by green colour mainly because it was a reminder of nature to majority of the respondents. The colour green-yellow had the lowermost number of affirmative outcomes because of its association to vomit and produced the feelings of disgust and sickness. Brennan and Charbonneau (2005) examined the effect on response rates for questionnaire of four different colours that included green, red, purple and blue. In a survey of sixteen hundred New Zealand residents which were taken at random from the New Zealand Electoral Roll, the different coloured questionnaires created significantly different response rates, ranging from sixty per cent to seventy-one per cent. Overall the most effective colour was purple. Westland and Shin (2015) studied the relationship between colour choice of consumer products and relationship of this choice with consumer colour preferences for personal care products. Digital images of products were obtained and manipulated to generate images of warmer and colder hues. An on-line questionnaire was constructed which was completed by 241 participants from 17 countries. It was found that the relationship between colour preferences and consumer's choice of products was complicated but while focusing only on hue and choice of personal care products, evidence suggested that consumers made product choice based on their colour preferences. The consequence was significant in all the products tested. Motoki et al. (2019) studied the effects of correspondences between visual and somatosensory (color and warmth) for the formation of attitudes and preferences towards sensory experiences. The results of the study suggested that there were novel correspondences between level of color lightness and thermal sensations.

\section{Gender differences in colour perception} In their study, Gollety and Guichard (2011) assessed the role played by colour and its impact on choice of children. The authors carried out an experiment on the children between the ages of 7 and 11 . The outcomes of the study showed that the most commonly liked colours among children were red, blue and purple. It was also found that among preference for flavour and colour there was a difference between the two genders with girls having higher preference for flavours and boys having higher preference for colours. Funk and Ndubisi (2006) studied the impact of colour on choice of consumers regarding automobiles along with the effect of differences based on gender. In order to understand these impacts, a field research of 196 Malaysian consumers was conducted. The results showed that colour attractiveness, attitude towards colour, normative colour and preferences of colour were significantly associated with choice of product. The outcomes also depicted that the influence of colour significance on choice was substantially higher for male customers as compared to female customers, the impact on choice based on attitude towards colour was significantly greater for female customers than for male customers and the influence on choice based on colour attractiveness was significantly higher for female customers in comparison to male customers. Sliburyte and Skeryte (2014) through an empirical research revealed that perception of colour depended only partly on demographic factors. The main reason behind the research was to examine the perception regarding colour in various marketing decisions. The primary data was collected through online questionnaires. Consumers' answers were obtained via 16 closed and open-ended questions using a survey of a random sample of 429 consumers which included 169 women and 260 men from Lithuania. As per the outcomes of this research, the favourable colour of the customers did not depend on their education or age-group. But it was found that the favourite colours were predetermined by gender of the respondents. The female respondents indicated blue, green and white as their favourite 
colour with much more statistical significance, while the men preferred red more than women. Certain colours were chosen more often by the consumers to express negative associations. Blue and black colours were associated with depression the most frequently; fire and danger with red, fraud and greed with yellow, jealousy with green, death with black, cold with white colour.

\section{Memory associated with colours}

Siple and Springer (1983) conducted a study to describe more precisely the nature of memory for information of colour of the object. Results showed that, for brightness and hue, memory and preference were quite precise for the tested objects; nevertheless, all subjects recollected and also preferred every item to be more highly saturated. Contextual change produced no change in accuracy, which suggests that access to memory for colour of the object is independent of texture and shape information. Manav (2006) examined subsisting beliefs regarding colour with focus on associations of colours with emotions by deliberating on the use of colours as a means of communication to fulfil needs of people living in residential areas. Respondents from different age groups took part in the study with a total sample of fifty. The respondents were requested to match adjectives from a list with the proper samples of colour from the directory of a relatively popular colour producing Turkish firm. Outcomes indicated that the dependency was strong between the use and choice of green colour in residential areas. The change in value and saturation levels of colours brings about change in emotional responses. Aslam (2006) reviewed the meanings of colours in a marketing perspective that was cross-cultural. The author delineated the role of colour as a marketing cue and also reviewed their socio-cultural and psychological associations. Colours have a tendency of affecting the contextual interpretation of the situations or objects and colour preference of consumers can predict their behaviour. It was found that the meanings addressed to some colours may extend beyond cultural restrictions, while some may be restricted to regional differences. The use of some colours is uniquely culture specific and it is essential to discover the elucidation and influence of a chosen colour in the intended market before the launching of a product or promotion campaign. Tornetta et al. (2009) studied how colour influences consumers. The authors found that in order to maximize success with colour, it is essential to understand the psychological principles behind colour. Product branding, packaging and consumer awareness all operate on diverse psychological principles of associative learning. Thus, planning and anticipating how customers will behave in response to the selected colours is necessary. The authors also suggested that the identification of colour trends is imperative as colours trends are not everlasting and can fluctuate over a prolonged period of time. Therefore, it is noteworthy to stay updated with latest marketing research on colour. Kauppinen-Ra"isa"nen and Luomala (2010) tried to understand the part that package colours play in consumer's involvement with product through study of the relationship between colour meanings and product.

The authors applied the preference-consumption difference interview technique by conducting 18 individual in-depth interviews. This paper reveals the qualitative connections between packages colour meanings as well as product type and supports the significance of the functions emphasized by earlier researchers. Kareklas et al. (2013) highlighted the significance of automatic fondness for the colour white over black in advertising by examining the colours black and white in product choice contexts. Over the study which was conducted in three parts, the authors incorporated multiple Implicit Association Tests to evaluate automatic preferences for colours, races, products and advertisements. The authors demonstrated that automatic fondness for the white colour was a predictor of choice even when products in black colour were chosen by most of the individuals; and that prediction of choice was boosted with the use of explicit and automatic colour preference measures in close association. 
Beneke et al. (2015) investigated the influence packaging colour has on the consumers intent to purchase bottled water. The research design used for the purpose of the study was experimental. Data was collected with the help of a survey using mall intercept technique from South African consumers in supermarket stores within suburban areas. The findings showed that even though consumers appeared somewhat uninterested in colours, there was a substantial preference for neutral colours as opposed to warm and cool colours in packaged water bottles. It could also be inferred from the study that income had a significant influence in colour preference for bottled water, where people belonging to lower income groups preferred cold and warm colours and those belonging to higher income groups preferred neutral colours. Javed and Javed (2015) studied whether the colour of packaging of a product influences customers' buying preferences and whether this relationship is moderated by time pressure. This paper studied the significance of colour in influencing buyers' purchasing preferences when the time to do purchasing is limited. This research found that in comparison to time constraint the purchasing preference depended relatively more on the colour scheme in case of a customer. It was revealed that; time pressure had more importance as a moderating factor which had an impact on the influence of colour of packaging on customers' buying preferences. Babolhavaeji et al. (2015) addressed how managers and packaging designers faced difficulties and transferred the messages proposed by the organization through the colour of the product. In order to channelize the content of their messages in the right direction a correct grasping of the influence of the visual aspects was required and also finding a more suitable place against the products in competition. In this research, the authors had reviewed the appropriate research articles and described the reasons behind the role of colour in attracting the buyer. Roschk et al. (2016) presented a meta-analytic study of sixty-six research studies and 135 effects attuning the atmospheric effects of colour, scent and music on shopping outputs. The analysis revealed that surroundings in which scent or music were present yielded higher satisfaction, pleasure and behavioural intention ratings in comparison to environments in which these conditions were not present. It could be perceived that colours regarded as warm produced higher levels of arousal as compared the colours perceived as cooler, whereas cooler colours produced greater levels of satisfaction in comparison to warm colours. Nitse et al. (2004) inquired if the misrepresentation of colour using computer display equipment having inconsistently and inaccurately presented colours negatively effects satisfaction of a consumer with the purchase of items related to fashion on the internet. As part of an initial inquiry into consumer views a small study was taken up about fashion merchandise bought over the Internet. The study indicated loss of sales and customers because of sites related to e-commerce which were selling products that were not accurately representing the real colours of the products. Increase in discontent on behalf of consumers can lead to greater costs in both reverse logistics and customer service.

\section{OBJECTIVES}

1. To analyse colour preference based on gender of the respondents.

2. To study whether colour influences consumer's decision to purchase.

3. To know the role of colour in influencing consumer's brand recall.

4. To find whether cool, warm or neutral colours have an impact on purchase intention.

\section{Hypothesis}

On the basis of the objectives of this study and insights from literature reviewed, the following alternative hypothesis have been taken:

$\mathrm{H}_{1}$ : There is significant difference between the colour preferences based on gender of the respondents

$\mathrm{H}_{2}$ : Colour significantly influences consumer's purchase decisions. 
$\mathrm{H}_{3}$ : There is significant influence of colours on brand recall.

$\mathrm{H}_{4 \mathrm{a}}$ : There is a significant difference in customer's purchase intention for product with warm colours and cool colours.

$\mathrm{H}_{4 \mathrm{~b}}$ : There is a significant difference in customer's purchase intention for product with warm colours and neutral colours.

$\mathrm{H}_{4 \mathrm{c}}$ : There is a significant difference in customer's purchase intention for product with neutral colours and cool colours.

\section{METHODS}

\section{Research design}

The research design used in the present study was descriptive wherein both primary and secondary data was collected. Secondary data was collected through various databases like Emerald, ScienceDirect and Taylor \& Francis online using keywords like "colour perception", "colour meaning", "colour and behaviour". Primary data was collected through questionnaires.

\section{Sample Selection}

An online survey was conducted and the survey form was sent to 250 people using non-probability convenience sampling. Out of 250 people, 225 responded with 90 per cent response rate and these replies were used for further analysis.

\section{Sources of Data}

Survey method was employed to collect primary data. A literature review was conducted and utilized to source information, with which to articulate the research questionnaire that consisted of closed ended questions. In order to collect the data, the free survey software Google Forms was used. In the first part of the questionnaire closed ended questions based on 5-point Likert scale were included which ranged from highly disagree to highly agree. The next part of the questionnaire used digital images of a product (given in Figure 1) and Adobe Photoshop was used to digitally alter each image for generation of multiple images where two images were of a warmer hue (yellow, red), three images where the products were of a colder hue (green, blue, pink) and two images which were neutral colour (white, black). There were also similar images of banners with different colours (given in Figure 2).

\section{Tools used for the study}

Once questionnaires had been scrutinized for completion and missing information, data were analysed by means of a statistical package SPSS,
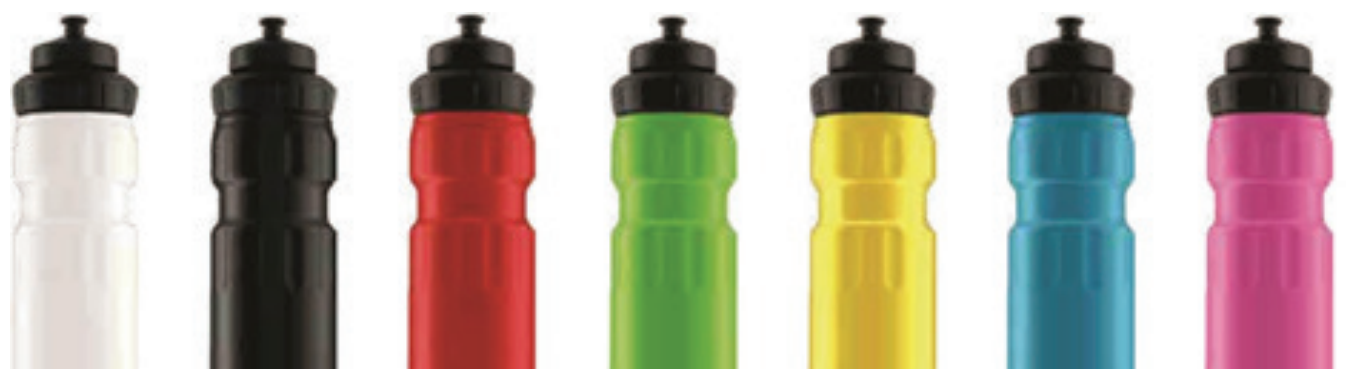

Figure 1. Seven images of a product in different colours

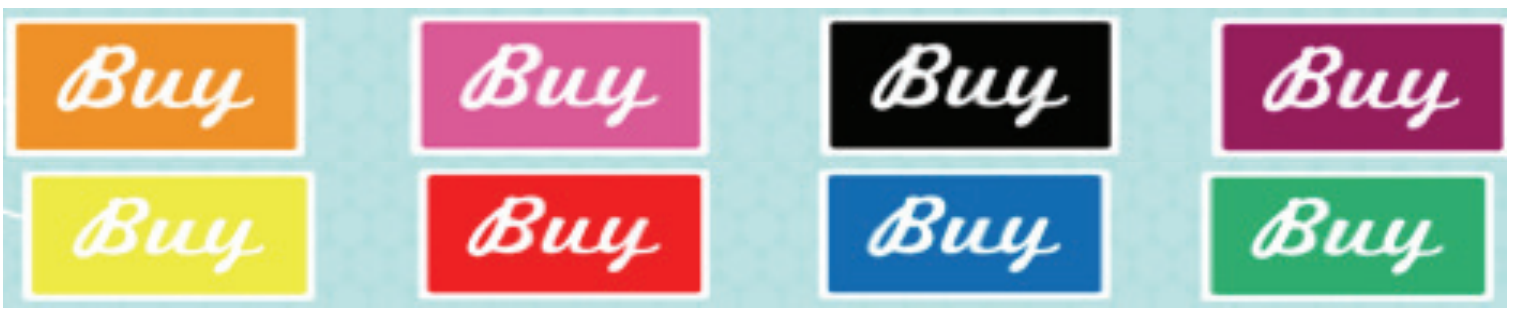

Figure 2. Banner in different colours 
version 23.0. Statistical tests used included percentage, mean, standard deviation and ANOVA.

\section{DATA ANALYSIS}

\section{Demographic details}

The data for demographic questions was analysed and it was found that 56.4 per cent were females and 43.6 per cent were males. Majority (67 per cent) of the respondents were in the age-group of 20 to 30 . Most of the respondents were either working (servicemen) or students with 47.6 per cent and 39.6 per cent respectively.

\section{Reliability}

The value of Cronbach's alpha was noted to be 0.868 , above the standard requirement of 0.7 representing a good amount of reliability (Hair et al., 2010).

\section{Analysis of product colour preference}

The most preferred colour among the respondents was blue (31\%) and the colour that was selected as least preferred was yellow (3\%); this result is in line with previous studies (Bellizzi and Hite, 1992; Tangkijviwat and Shinoda, 2008; Westland and Shin, 2015). It was also found that pink was significantly more preferred by females as compared to males and black was significantly more preferred by males as compared to females. Figure 3 shows the breakdown of colour preferences for product based on gender of the respondent.

Table 2. Descriptive Statistics

\begin{tabular}{|c|c|c|}
\hline Statements & Mean & Std. Deviation \\
\hline Colour Preferences & & \\
\hline Colour can improve comprehension & 3.82 & .91 \\
\hline $\begin{array}{l}\text { Colour tends to make marketing materials (ads, promotions etc.) more } \\
\text { readable than black and white }\end{array}$ & 4.06 & 1.09 \\
\hline Colour helps to remember more easily for longer time & 4.19 & .97 \\
\hline A colour of a product provides pleasure to me & 3.60 & 1.07 \\
\hline I relish seeing displays of products that are colourful & 3.95 & .99 \\
\hline Sometimes the colour of a product seems to reach out and seize me & 3.76 & 1.03 \\
\hline $\begin{array}{l}\text { When in an environment with cool colours (blue, green, purple), I have } \\
\text { a feeling of calmness and relaxation }\end{array}$ & 3.80 & 1.02 \\
\hline $\begin{array}{l}\text { Presence of colours like red, yellow, orange creates an environment of } \\
\text { warmth and energy }\end{array}$ & 3.84 & .94 \\
\hline $\begin{array}{l}\text { I enjoy eating at a restaurant with cool colours (like blue, green or } \\
\text { purple) }\end{array}$ & 3.38 & 1.21 \\
\hline Colour of a product seeks my attention & 3.83 & 1.02 \\
\hline \multicolumn{3}{|l|}{ Purchase Decision } \\
\hline Colour is prime reason to buy a particular product & 3.27 & 1.27 \\
\hline When the colour of a product appeals, I feel a strong urge to purchase it & 3.75 & 1.13 \\
\hline $\begin{array}{l}\text { When I see a new store or restaurant with striking colours, I usually } \\
\text { enter it }\end{array}$ & 3.40 & 1.10 \\
\hline \multicolumn{3}{|l|}{ Brand Recall } \\
\hline Colour can increase ability to recognize brands & 4.00 & .97 \\
\hline $\begin{array}{l}\text { Being able to differentiate between product/brand colours reduces } \\
\text { search time }\end{array}$ & 3.86 & .98 \\
\hline Colour is a good way to distinguish one brand from another & 3.64 & 1.13 \\
\hline $\begin{array}{l}\text { When I see a new or different colour brand, I often pick it up to see } \\
\text { what it is like }\end{array}$ & 3.74 & 1.01 \\
\hline $\begin{array}{l}\text { While buying an unfamiliar brand its colour helps me in making the } \\
\text { decision }\end{array}$ & 3.30 & 1.23 \\
\hline
\end{tabular}

Source: Survey by authors 


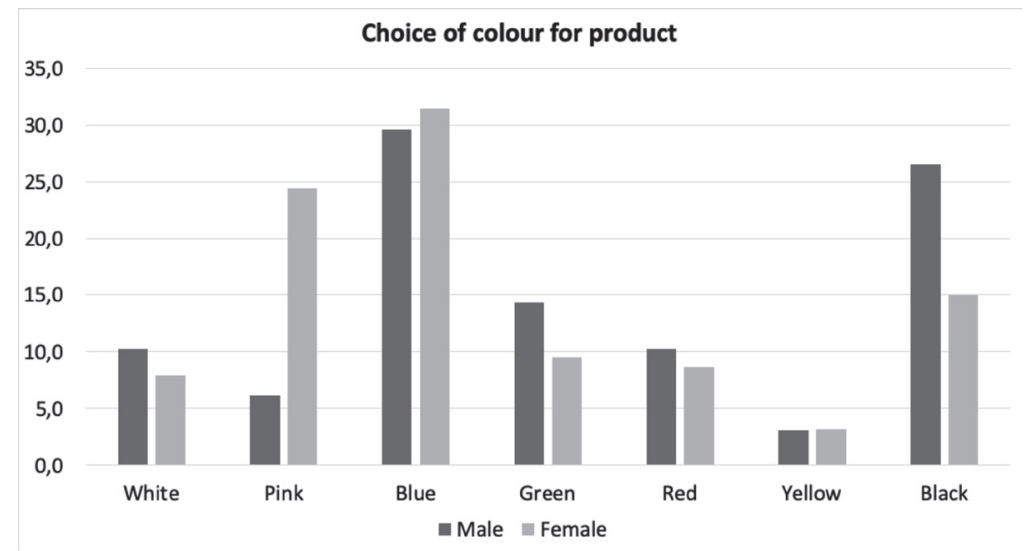

Figure 3. Choice of colour for product based on gender

\section{Analysis of banner colour preference}

The most preferred colour for banner that was chosen was red (24\%) and the colour that was selected as least preferred was yellow (4\%). It was found that warm colours (red, pink, orange) were more preferred by females whereas cool colours (green, blue) were more preferred by males. Figure 4 shows the breakdown of colour preferences for banner based on gender of the respondent.

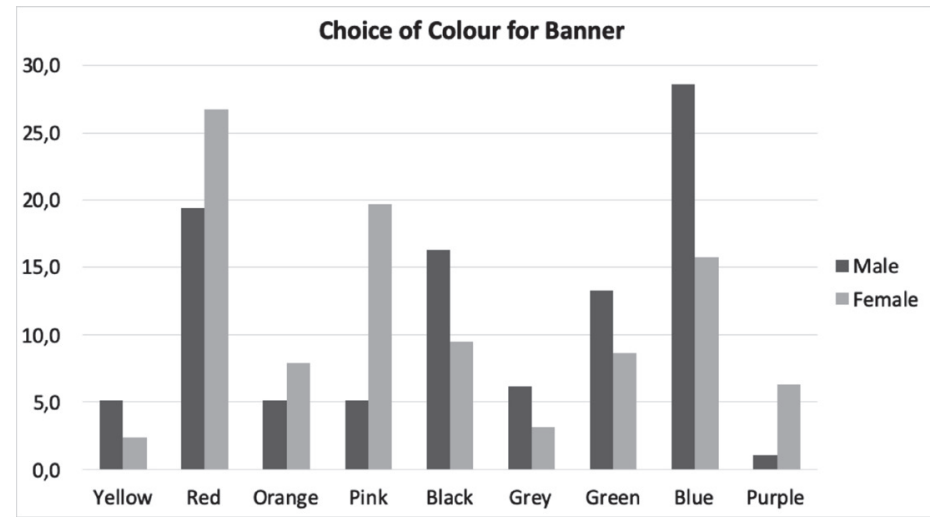

Figure 4. Choice of banner based on gender

Table 3. Independent Samples t-Test

\begin{tabular}{|c|c|c|c|c|c|c|}
\hline & & \multicolumn{2}{|c|}{$\begin{array}{c}\text { Levene's Test for } \\
\text { Equality of Variances }\end{array}$} & \multicolumn{3}{|c|}{ t-test for Equality of Means } \\
\hline & & $\mathrm{F}$ & Sig. & $\mathrm{t}$ & df & $\begin{array}{c}\text { Sig. } \\
\text { (2-tailed) }\end{array}$ \\
\hline \multirow[t]{2}{*}{ Choice of Product } & $\begin{array}{l}\text { Equal variances } \\
\text { assumed }\end{array}$ & 2.432 & .120 & 2.619 & 223 & .009 \\
\hline & $\begin{array}{l}\text { Equal variances not } \\
\text { assumed }\end{array}$ & & & 2.589 & 198.803 & .010 \\
\hline \multirow[t]{2}{*}{$\begin{array}{l}\text { Choice of banner } \\
\text { for a retail outlet }\end{array}$} & $\begin{array}{l}\text { Equal variances } \\
\text { assumed }\end{array}$ & .038 & .845 & 1.836 & 223 & .050 \\
\hline & $\begin{array}{l}\text { Equal variances not } \\
\text { assumed }\end{array}$ & & & 1.834 & 208.108 & .050 \\
\hline
\end{tabular}

Source: Survey by authors 
Influence of colour on consumer's purchase decision and brand recall

Pearson's correlation was applied in order to find whether relationship existed between colour preferences, purchase decision and brand recall. It was found that significant relationship existed between all three variables. As significant correlation existed, further regression analysis was employed to find the influence of colour on purchase decisions. The results suggested that there was significant $(\beta=.587, \mathrm{t}=10.836, \mathrm{p}<.001)$ influence of colour on purchase decision and it predicted 34.5 per cent variation in purchase decision. Similar results were found in previous studies where the environmental colour influenced purchase decisions with higher intention to purchase in a shopping environment where the colour of background of a retail display was blue rather in place of red (Bellizzzi and Hite, 1992). Labrecque and Milne (2012) found that brand personality perceptions influenced by colour can affect purchase decisions. Another study found that in case of fashion accessories, colour is used as a selection criterion while making the buying decision as well as driver of satisfaction once the item has been received (Nitse et al., 2004). The outcomes of this research add to the results of previous researchers regarding the influence of colour in making purchase decisions. Hence, hypothesis $\mathrm{H}_{2}$ was accepted.
To test whether colour preference influenced brand recall, regression analysis was applied again. Significant influence existed $(\beta=.669, \mathrm{t}=13.451$, $\mathrm{p}<.001$ ) on brand recall and colour predicted 44.8 per cent variations in brand recall. While buying an unfamiliar brand its colour helps in making the decision. For example, red is linked with CocaCola, blue is associated with Facebook, pink with Barbie dolls, purple with Cadbury's, green with 7-Up, red and white with Airtel. These results were found consistent with previous studies which also suggested that colour assists in brand recall (Percy and Rossiter, 1983; Tavassoli and Han, 2002). Hence, hypothesis $\mathrm{H}_{3}$ was accepted.

\section{Influence of different colours on consumer's purchase intentions}

ANOVA was applied on the purchase intention of customers for different colour groups (warm, cool and neutral). Table 5 shows test statistic of 4.202 at 5 per cent level of significance with a p-value of 0.016 . Therefore, it was concluded that there is difference of opinion regarding purchase intention of customers for different colour groups. Hence, hypothesis $\mathrm{H}_{4 \mathrm{a}}, \mathrm{H}_{4 \mathrm{~b}}$ were accepted and hypothesis $\mathrm{H}_{4 \mathrm{c}}$ was rejected.

In addition, to understand the underlying differences, post-hoc analysis using LSD (Least

Table 4. Correlations

\begin{tabular}{llccc}
\hline & & $\begin{array}{c}\text { Purchase } \\
\text { Decision }\end{array}$ & $\begin{array}{c}\text { Colour } \\
\text { Preference }\end{array}$ & Brand Recall \\
\hline Purchase & Pearson Correlation & 1 & $.587^{* *}$ & $.541^{* *}$ \\
Decision & Sig. (2-tailed) & & .000 & .000 \\
& $\mathrm{~N}$ & 225 & 225 & 225 \\
Colour & Pearson Correlation & $.587^{* *}$ & 1 & $.669^{* *}$ \\
Preference & Sig. (2-tailed) & .000 & & .000 \\
& $\mathrm{~N}$ & 225 & 225 & 225 \\
Brand Recall & Pearson Correlation & $.541^{* * *}$ & $.669^{* *}$ & 1 \\
& Sig. (2-tailed) & .000 & .000 & \\
& $\mathrm{~N}$ & 225 & 225 & 225 \\
\hline
\end{tabular}

**. Correlation is significant at the 0.01 level (2-tailed).

Source: Survey by authors 
Table 5. ANOVA Purchase Intention for different colours

\begin{tabular}{lccccc}
\hline & Sum of Squares & df & Mean Square & F & Sig. \\
\hline Between Groups & 4.967 & 2 & 2.483 & 4.202 & .016 \\
Within Groups & 131.193 & 222 & .591 & & \\
Total & 136.160 & 224 & & & \\
\hline
\end{tabular}

Source: Survey by authors

Table 6. Multiple Comparisons

\begin{tabular}{llccccc}
\hline \multirow{2}{*}{ (I) Colour } & (J) Colour & Difference (I-J) & Std. Error & Sig. & Lower Bound & Upper Bound \\
\hline \multirow{2}{*}{ Neutral } & Cool & .06348 & .11648 & .586 & -.1661 & .2930 \\
& Warm & $-.39954^{*}$ & .17377 & .022 & -.7420 & -.0571 \\
Cool & Neutral & -.06348 & .11648 & .586 & -.2930 & .1661 \\
& Warm & $-.46302^{*}$ & .15995 & .004 & -.7782 & -.1478 \\
Warm & Neutral & $.39954^{*}$ & .17377 & .022 & .0571 & .7420 \\
& Cool & $.46302^{*}$ & .15995 & .004 & .1478 & .7782 \\
\hline
\end{tabular}

* The mean difference is significant at the 0.05 level.

Dependent Variable: Purchase Intention

Method used: LSD

Source: Survey by authors

Significant Difference) was conducted as shown in table 6 . It revealed that there was a significant difference between purchase intention for warm and cool colours as well as warm and neutral colours although there was no significant difference between purchase intention for neutral and cool colours. This may be due to the fact that there is a high contrast in the warm and cool colours as well as warm and neutral colours due to the high difference in wavelengths. On the other hand, the difference is much lesser in neutral and cool colours which may have resulted in no significant difference for purchase intention between these two colours.

\section{RESULTS AND DISCUSSION}

The results of present research show that colour plays a significant role in consumer's choice of products. This fact was observed in previous studies as well, where the colour of a product, promotional material or retail environment influenced customer's behaviour to a large extent. Through this study, it was found that the colour most preferred was blue and the least preferred was yellow among both males and females. For choice of banner (an advertising material) also the results were same with blue being the most preferred (although red was also a close choice) and yellow being the least preferred. These differences may be due to the opposing nature of the two colours with warm colours used for arousal and cool colours used for creating a calming effect (Grossman and Wisenblit, 1999). Another factor that affects colour associations is the situation or the environment for example, in 1956 Kreitler found that there was a disliking for the yellow colour because of its linkage with the yellow patch worn by Nazis. However, on repeating the experiment was in 1960 on the next generation the people reported a liking for the yellow colour because it depicted rebirth (Kreitler and Kreitler, 1972). Further, for differentiating between choices of both genders, t-test was employed and the results suggested that significant difference existed. Thus, hypothesis $\mathrm{H}_{1}$ that significant difference exists between the colour preferences based on gender of the respondents was accepted.

The results also suggested that colours influence customer's purchase decision and brand recall. 
Thus, the hypothesis $\mathrm{H}_{2}$ and hypothesis $\mathrm{H}_{3}$ that colour plays a significant role in influencing consumer's purchase decisions and brand recall respectively were both accepted. This fact can also be attributed to colour associations developed in customer's mind due to previous experiences. Next important finding was regarding the influence of different colours on consumer's purchase intentions. It was found that there was difference of opinion regarding purchase intention of customers for different colour groups. It was revealed that there was a substantial difference between purchase intention for warm and cool colours as well as warm and neutral colours although there was no significant difference between purchase intention for neutral and cool colours. Hence, hypothesis $\mathrm{H}_{4 \mathrm{a}}, \mathrm{H}_{4 \mathrm{~b}}$ were accepted and hypothesis $\mathrm{H}_{4 \mathrm{c}}$ was rejected. This may be due to similar connotations between cool and neutral colours; some colours like white which are considered both cool and neutral may also add to this association (Chebat and Morrin, 2007).

\section{MANAGERIAL IMPLICATIONS}

This study has several implications for marketers. Firstly, marketers should consider the colour of packaging, their product's colour and all colours that are related to the product during advertising, as part of market strategy of their products. The present study recommends that with the development of effective methods for the collection of data, information regarding consumer's personal colour preferences could help in modifying products offerings that could in turn enhance the possibility of increase in sales. Lastly, use of a contrasting colour could be an asset for better distinguishability on the shelves, only if the colour is suitable for the concerned category of product.

\section{CONCLUSION}

Although colour literature is vast, theories of colour in marketing are not yet advanced. There have been several studies to give meanings and associations to colours (Aslam, 2006; Kauppinen-Räisänen and Luomala, 2010). These studies mainly focused on symbolic meanings and associations of colours in different cultures, but what really is required is to understand meanings of colours as a vital part of logos, packages, services, products and displays besides understanding individual differences in colour preferences. The use of colours differs based on gender along with the effect of attitude and attractiveness towards colour on choice which is significantly higher for female consumers as compared to male consumers (Funk and Ndubisi, 2006). This study too found certain differences in customer's colour preferences with pink being more preferred by females and blue being preferred by males although overall blue was the most preferred colour. This result can be attributed to the fact that hue preferences of females shifted to longer wavelengths (warmer colours) when compared with those of males (Hurlbert and Ling, 2007). Thus, the first hypothesis was also accepted.

This study further utilized correlation and regression analysis in order to find whether colour influences consumer's product decisions and it was found that colour has a significant impact on their decision making which led to the acceptance of the second hypothesis. It is a powerful cue for creation and sustenance of corporate identities (Garber et al., 2000) and for brand and product differentiation (Schmitt and Pan, 1994) and consumer perceptions (Grossman and Wisenblit, 1999). Colour indicates the attributes of a product. For example, the colour of food affects the propensity of consumers to correctly detect flavour and other sources of flavour information are dominated by it, including taste and labelling (Garber et al., 2000). It implies that alteration in the food colour could affect consumer preferences. Colour is instrumental in appealing consumer attention to advertisements. As found in a study by Lee and Barnes (1989) that there was correlation between the product, colour of print advertisements as well as the product and type of magazine and there were variances in the usage of colour. Another important finding of the study was that colour influences brand recall. Thus, third hypothesis was accepted. Gatorade, Apple, M\&Ms have used this characteristic of colour regarding 
brand recall in an effective manner by the launch of novel coloured product lines (Garber et al., 2000), while Pepsi has tried forming new colour associations by choosing blue as its colour after leaving the conventional red colour associated with cold drinks (Grossman and Wisenblit, 1999). Lastly, it was also found that consumer's purchase intention differed significantly for warm and cool colours as well as warm and neutral colours but there was no significant difference in purchase intention for neutral and cool colours. Thus, the fourth hypothesis was partially accepted as there was acceptance for first two parts of this hypothesis.

REFEREN CES

Abril, P. S., Olazábal, A. M., \& Cava, A. (2009). Marketing and the law. Journal of the Academy of Marketing Science, 37(3), 375-377.

Aslam, M. M. (2006). Are you selling the right color? A cross $\square$ cultural review of color as a marketing cue. Journal of marketing communications, 12(1), 15-30.

Babolhavaeji, M., Vakilian, M. A., \& Slambolchi, A. (2015). The role of product color in consumer behaviour. Advanced Social Humanities and Management, 2(1), 9-15.

Bellizzi, J. A., \& Hite, R. E. (1992). Environmental color, consumer feelings, and purchase likelihood. Psychology \& marketing, $9(5), 347-363$

Bellizzi, J. A., Crowley, A. E., \& Hasty, R. W. (1983). The effects of color in store design. Journal of Retailing, 59(1), 21-45.

Beneke, J., Mathews, O., Munthree, T., \& Pillay, K. (2015). The role of package color in influencing purchase intent of bottled water: Implications for SMEs and entrepreneurs. Journal of Research in Marketing and Entrepreneurship, 17(2), 165-192.

Brennan, M., \& Charbonneau, J. (2005). The color purple: The effect of questionnaire color on mail survey response rates. Marketing Bulletin, 16(5), 1-7.

Chebat, J. C., \& Morrin, M. (2007). Colors and cultures: exploring the effects of mall décor on consumer perceptions. Journal of business Research, 60(3), 189-196.

Crowley, A. E. (1993). The two-dimensional impact of color on shopping. Marketing Letters, 4(1), 59-69.

Elliot, A. J., \& Maier, M. A. (2007). Color and Psychological Functioning. Current Directions in Psychological Science, 16(5), $250-254$

Elliot, A. J., Maier, M. A., Moller, A. C., Friedman, R., \& Meinhardt, J. (2007). Color and psychological functioning: the effect of red on performance attainment. Journal of Experimental Psychology: General, 136(1), 154-168.

Funk, D., \& Oly Ndubisi, N. (2006). Color and product choice: a study of gender roles. Management research news, 29(1/2), 41-52.

Garber Jr, L. L., Hyatt, E. M. \& Starr Jr, R. G. (2000) The effects of food color on perceived flavor, Journal of Marketing Theory and Practice, 8(4), 59-72.

Gollety, M., \& Guichard, N. (2011). The dilemma of flavor and color in the choice of packaging by children. Young Consumers, $12(1), 82-90$.

Hair, J. F. (2010). Black, WC, Babin, BJ, \& Anderson, RE (2010). Multivariate data analysis, 7.

Hurlbert AC and Ling Y (2007), Biological components of sex differences in color preference, Current Biology, 17 (16), R623-R625.

Javed, S. A., \& Javed, S. (2015). The impact of product's packaging color on customers' buying preferences under time pressure. Marketing and Branding Research, 2(1), 4.

Kareklas, I., Brunel, F. F., \& Coulter, R. (2012). Judgment is not color blind: The impact of automatic color preference on product and advertising preferences. 
Kauppinen - Räisänen, H., \& Luomala, H. T. (2010). Exploring consumers' product-specific color meanings. Qualitative Market Research: An International Journal, 13(3), 287-308.

Kaya, N. \& Epps, H. (2004). Relationship between color and emotion: A study of college students. College Student J, 38(3), 396. Kreitler, H. and Kreitler, S. (1972), Psychology of the Arts, Duke University Press, Durham, NC.

Labrecque, L. I., \& Milne, G. R. (2012). Exciting red and competent blue: the importance of color in marketing. Journal of the Academy of Marketing Science, 40(5), 711-727.

Lee, S. \& Barnes Jr, J. H. (1989) Using color preferences in magazine advertising, Journal of Advertising Research, 29(6), 25-30.

Manav, B. (2007). Color emotion associations and color preferences: A case study for residences. Color Research \& Application, 32(2), 144-150.

Motoki, K., Saito, T., Nouchi, R., Kawashima, R., \& Sugiura, M. (2019). Light colors and comfortable warmth: Crossmodal correspondences between thermal sensations and color lightness influence consumer behavior. Food quality and preference, $72,45-55$.

Nitse, P. S., Parker, K. R., Krumwiede, D., \& Ottaway, T. (2004). The impact of color in the e-commerce marketing of fashions: an exploratory study. European Journal of Marketing, 38(7), 898-915.

Percy, L. and Rossiter, J. (1983). Effects of picture size and colour on brand attitude responses in print advertising, Advances in Consumer Research, 10(1), 17-20.

Priluck Grossman, R., \& Wisenblit, J. Z. (1999). What we know about consumers' color choices. Journal of marketing practice: Applied marketing science, 5(3), 78-88.

Roschk, H., Loureiro, S. M. C., \& Breitsohl, J. (2017). Calibrating 30 Years of Experimental Research: A Meta-Analysis of the Atmospheric Effects of Music, Scent, and Color. Journal of Retailing, 93(2), 228-240.

Schmitt, B. H. \& Pan, Y. (1994) Managing corporate and brand identities in the Asia-Pacific region, California Management Review, 36(4), 32-48.

Singh, S. (2006). Impact of color on marketing. Management decision, 44(6), 783-789.

Siple, P., \& Springer, R. M. (1983). Memory and preference for the colors of objects. Attention, Perception, \& Psychophysics, 34(4), 363-370.

Sliburyte, L., \& Skeryte, I. (2014). What we know about consumers' color perception. Procedia-Social and Behavioral Sciences, $156,468-472$.

Tangkijviwat, U., \& Shinoda, H. (2008). Color preference approached from perceived color attributes for different color appearance mode. In Proceedings of the Interim Meeting of the International Color Association.

Tornetta, S., Fox, T. \& Blackbird, J. (2009). Color sells: The psychology of color influences consumers.

Tavassoli, N. T. \& Han, J. K. (2002). Auditory and visual brand identifiers in Chinese and English, Journal of International Marketing, 10(2), 13-28.

Westland, S., \& Shin, M. J. (2015). The relationship between consumer color preferences and product-color choices. JAICJournal of the International Color Association, 14 